\title{
EFEKTIFITAS CAMPURAN RENDAMAN JERAMI PADI (ORYZA SATIVA L) DAN TEMEFOS SEBAGAI ATRAKTAN TERHADAP LETHAL OVITRAP AEDES AEGYPTI L
}

\section{Effectivity of Rice Straw Immersion (Oryza sativa L) and Temephos as Attractant to Lethal Ovitrap Aedes aegypti $L$}

\author{
Muhammad Rasyid Ridha ${ }^{1}$, Budi Hairani ${ }^{1}$, Gusti Melyanie ${ }^{1}$, Wulan Sari Rasna Giri Sembiring ${ }^{1}$, \\ Abdullah Fadilly ${ }^{1}$, Akhmad Rosanji ${ }^{1}$ \\ ${ }^{1}$ Balai Litbang Kesehatan Tanah Bumbu, Jalan. Lokalitbang, Kawasan Perkantoran Pemda Kabupaten \\ Tanah Bumbu, Kalimantan Selatan, Kotak Pos 666 \\ Email: ridho.litbang@gmail.com
}

Diterima: 6 April 2020; Direvisi: 29 Mei 2020; Disetujui: 23 September 2020

\begin{abstract}
Dengue hemorrhagic fever is a global health problem and can be transmitted through vectors, namely Aedes aegypti. One of the controls can be through lethal ovitrap combined with attractant. This study aims to compare the percentage of trapped eggs, the number of eggs hatched, and larval mortality in the lethal ovitrap that were given two additional types of attractants. The insecticides used were temephos, while the attractants used were $20 \%$ rice straw soaking water, and water that Aedes aegypti have used to lay eggs. The type of research is an experiment with a completely randomized design. The sample used was female mosquito of Aedes aegypti that is full of blood from laboratory colonization. The results showed that rice straw soaking water was more influential attractant than the former Aedes aegypti colonization water in attracting Aedes aegypti mosquitoes to lay eggs. The highest larval mortality was found in a combination of lethal ovitrap with rice straw soaking water. Statistically there is an influence of the type of attractant on hatchability and the development of Aedes aegypti into adult mosquitoes. The combination of lethal ovitrap and attractant of rice straw soaking water can be an alternative control strategy for dengue hemorrhagic fever program managers to reduce the density of Aedes aegypti mosquitoes and minimize transmission of dengue hemorrhagic fever in an area.
\end{abstract}

Keywords: Aedes aegypti, attractant, lethal ovitrap, straw soaking water

\begin{abstract}
ABSTRAK
Demam berdarah dengue merupakan masalah kesehatan global dan dapat ditularkan melalui vektor yaitu Aedes aegypti. Salah satu pengendaliannya dapat melalui lethal ovitrap yang dipadukan dengan atraktan. Penelitian ini bertujuan untuk membandingkan persentase jumlah telur terperangkap, jumlah telur menetas, dan mortalitas larva pada lethal ovitrap yang diberi tambahan dua jenis atraktan. Insektisida yang digunakan adalah temefos, sedangkan atraktan yang digunakan adalah air rendaman jerami padi dengan konsentrasi 20\%, dan air bekas kolonisasi/telur larva Aedes aegypti. Jenis penelitian ini adalah eksperimen dengan rancangan acak lengkap. Sampel yang digunakan adalah nyamuk Aedes aegypti betina yang kenyang darah hasil kolonisasi di laboratorium. Hasil penelitian menunjukkan bahwa air rendaman jerami merupakan atraktan yang lebih berpengaruh dibandingkan air bekas kolonisasi Aedes aegypti dalam menarik nyamuk Aedes aegypti untuk bertelur. Mortalitas larva tertinggi terdapat pada kombinasi lethal ovitrap dengan air rendaman jerami padi. Secara statistik ada pengaruh jenis atraktan terhadap daya tetas dan perkembangan Aedes aegypti menjadi nyamuk dewasa. Kombinasi lethal ovitrap dengan atraktan air rendaman jerami padi dapat menjadi strategi pengendalian alternatif bagi pengelola program DBD untuk mengurangi kepadatan nyamuk Aedes aegypti dan meminimalisasi transmisi penyakit demam berdarah dengue di suatu wilayah.
\end{abstract}

Kata kunci: Aedes aegypti, atraktan, lethal ovitrap, rendaman jerami 


\section{PENDAHULUAN}

Demam berdarah dengue (DBD) merupakan masalah kesehatan global. Penularan DBD melalui gigitan nyamuk Aedes sp. yang membawa virus dengue. Aedes aegypti dan Ae. albopictus merupakan vektor utama DBD dan tersebar merata di seluruh dunia. Spesies Aedes lain juga dilaporkan berpotensi sebagai virus DBD yaitu Aedes mediovittatus di daerah karibia,(Poole-smith et al., 2015) dan Aedes niveus di wilayah Serawak, Malaysia (Young et al., 2017) (Nurin et al., 2015).

Indonesia ditetapkan sebagai salah satu negara hiperendemik dengan 34 provinsi yang terkena DBD oleh World Health Organization (WHO) (Ariani and Widana, 2016), Jumlah kasus DBD di Indonesia fluktuatif setiap tahunnya. Data dari Direktorat Pencegahan dan Pengendalian Penyakit Tular Vektor dan Zoonotik Ditjen P2P Kemenkes RI, pada tahun 2014 jumlah penderita mencapai 100.347 dengan 907 diantaranya meninggal (Kemenkes, 2017). Tahun 2015, sebanyak 129.650 penderita dan 1.071 kematian, dan pada 2016 sebanyak 202. 314 penderita dan 1.593 kematian (Kemenkes, 2017). Angka kesakitan atau Incidence rate (IR) di 34 provinsi pada tahun 2015 mencapai 50,75 per 100 ribu penduduk, sedangkan tahun 2016 IR mencapai 78,85 per 100 ribu penduduk (Kemenkes, 2017). Angka ini masih lebih tingggi dari target IR nasional yaitu 49 per 100 ribu penduduk.

Upaya pengawasan dan pengendalian yang dilakukan untuk menekan kasus DBD diantaranya melalui pengamatan vektor DBD (surveilance) secara berkala. Tujuannya untuk mengidentifikasi wilayah yang memiliki kepadatan nyamuk yang tinggi atau untuk mendeteksi periode peningkatan populasi nyamuk. Metode yang dilakukan untuk kegiatan surveilans untuk mendeteksi adanya investasi nyamuk Ae.aegypti di suatu wilayah adalah survei jentik, survei nyamuk dewasa, dan survei telur. Survei telur efektif digunakan untuk mendeteksi keberadaan nyamuk Ae.aegypti, bahkan pada saat kepadatan vektor berada pada level rendah (Codeço et al., 2015).

\begin{tabular}{crrr} 
Penggunaan & \multicolumn{2}{c}{ perangkap telur } \\
(ovitrap) & merupakan & salah satu & cara
\end{tabular}

pengendalian Aedes sp. yang cukup efektif tanpa mengggunakan bahan insektisida dan berhasil dalam menurunkan densitas vektor di beberapa negara, namun diperlukan pengawasan secara berkala untuk melihat keberadaan telur dan jentik di di dalam ovitrap (Wahidah, Martini and Hestiningsih, 2016).

Ovitrap pertama kali dikembangkan oleh Fay dan Eliason pada tahun 1996, kemudian digunakan oleh Central for Diseases Control and Prevention (CDC) dalam surveilan Ae.aegypti (Rati, Hasmiwati and Rustam, 2016). Ovitrap digunakan untuk suvei telur dan dirancang untuk menarik nyamuk betina meletakkan telurnya disitu, kemudian dihitung dan diidentifikasi (Milana Salim and Tri Baskoro Tunggul Satoto, 2015). Menurut Zeichner dan Perich dalam Milana, modifikasi ovitrap juga dilakukan dengan menambahkan beberapa jenis insektisida pada media bertelur sebagai lethal ovitrap (Milana Salim and Tri Baskoro Tunggul Satoto, 2015). Penambahan atraktan juga dapat dilakukan untuk menarik penciuman nyamuk agar mau bertelur pada ovitrap (Ariani and Widana, 2016).

Atraktan adalah zat penarik nyamuk untuk datang ke suatu tempat (Milana Salim and Tri Baskoro Tunggul Satoto, 2015). Atraktan dapat berasal dari tanaman yang mudah ditemukan di sekitar kita atau bahan lain yang mempunyai aroma dan zat yang dapat menarik nyamuk untuk bertelur (Milana Salim and Tri Baskoro Tunggul Satoto, 2015). Geirer dalam Wahidah, et al. mengatakan atraktan dapat digunakan untuk mempengaruhi perilaku memonitor atau menurunkan populasi nyamuk secara langsung, tanpa menyebabkan cedera bagi binatang lain dan manusia, serta tidak meninggalkan residu pada makanan atau bahan pangan (Wahidah, Martini and Hestiningsih, 2016).

Berbagai hasil penelitian menyatakan banyak media yang dapat dijadikan sebagai atraktan, diantaranya fermentasi gula, (Sari;, Octaviana and Wijayanti, 2017), ragi tape dan ragi gula (Kesehatan, Volume and Atraktan, 2015), Cabai merah (Capsicum annum L) dan Tebu (Saccharum officinarum L), namun beberapa media yang telah disebutkan tersebut dalam pembuatannya 
memerlukan jumlah bahan yang banyak serta waktu yang lama. Berdasarkan pertimbangan tersebut dilakukan pengujian dengan rendaman jerami yang sudah terbukti efektif dan mudah didapatkan dibandingkan dengan air bekas telur (ABT), serta dengan menambahkan Temefos yang sampai saat ini digunakan program dalam pengendalian DBD sebagai lethal ovitrap dalam pengendalian Ae. aegypti.

\section{BAHAN DAN CARA}

Penelitian ini dilakukan di Laboratorium Entomologi Balai Litbangkes Tanah Bumbu. Waktu pelaksanaan mulai bulan Januari sampai dengan bulan April 2018. Populasi pada penelitian ini adalah nyamuk Ae. aegypti hasil kolonisasi Laboratorium Entomologi Balai Litbangkes Tanah Bumbu fenotif/keturunan ke 247. Sampel untuk pengujian atraktan terhadap oviposisi adalah nyamuk betina dengan kondisi gravid. Sampel penelitian didapatkan dengan cara melakukan rearing/kolonisasi di laboratorium.

Sekitar 500 butir telur Ae. aegypti hasil kolonisasi laboratorium ditetaskan dan dikembangkan hingga menjadi nyamuk dewasa. Pada tahap pupa, wadah berisi pupa dimasukkan ke dalam kandang nyamuk, sehingga nyamuk yang menetas dari pupa dapat segera melakukan perkawinan. Diberikan pakan larutan sukrosa $10 \%$ dan pakan darah marmut. Kondisi perut nyamuk diamati, apabila bagian abdomen/perut terlihat penuh dan bewarna merah, nyamuk betina tersebut dianggap telah kenyang darah (full blood) dan siap sebagai sampel penelitian. Selanjutnya, sebanyak 125 nyamuk betina yang kenyang darah dipisahkan ke kandang lain. Nyamuk betina tersebut akan mematangkan telurnya dalam waktu sekitar 3-4 hari dan menjadi nyamuk gravid.

Ovitrap dibuat menggunakan gelas plastik volume $220 \mathrm{ml}$, ovistrip berupa kertas saring berukuran panjang $20 \mathrm{~cm}$ dan lebar 5 $\mathrm{cm}$ dipasang melingkar pada $1 / 3$ bagian atas mulut gelas. Ovistrip dipasang pada saat akan dilakukan pengujian setelah gelas diisi berbagai jenis air sebagai media uji. Volume media uji ditetapkan sebanyak $150 \mathrm{ml}$.
Larutan temefos $0,2 \%$ merupakan $0,625 \mathrm{ml}$ temefos cair ditambah aquades sebanyak 100 $\mathrm{ml}$ sehingga diperoleh lauran temefos $0,2 \%$. Untuk kontrol ditambah dengan aquades, sedangkan perlakuan ditambah dengan larutan rendaman jerami padi (Oryza sativa L) dan air bekas telur. Atraktan yang digunakan adalah air rendaman jerami konsentrasi $20 \%$ dan air bekas telur larva $A e$. aegypti dengan konsentrasi 150 larva/600ml air. Air rendaman jerami dibuat dari 125 gram jerami kering, dipotong dan direndam dalam 15 liter air dan didiamkan di dalam ember plastik bertutup rapat selama 7 hari. Sebagai kontrol digunakan aquades.

Jenis penelitian adalah eksperimen menggunakan rancangan acak lengkap (RAL). Ada enam kombinasi bahan yang diujikan pada sampel penelitian yakni air bekas telur (ABT), air rendaman jerami padi (ARJP), ABT ditambah Temefos (ABTT), air rendaman jerami padi ditambah temefos (ARJPT), aquades ditambah temefos (AqT), dan aquades sebagai kontrol (K). Pengulangan dilakukan sebanyak empat kali. Efektivitas atraktan dianalisis dengan uji ANOVA (Analysis of Variance) dan uji lanjut LSD (Least Significance Difference). Jika normalitas data tidak terpenuhi maka digunakan uji Kruskal Wallis. Normalitas data diuji dengan uji Kolmogorov-Smirnof.

Enam ovitrap diletakkan secara acak di dalam kandang berukuran $45 \mathrm{~cm} 3$ dengan pola lingkaran. Setelah dibiarkan selama satu jam, dimasukkan 25 ekor nyamuk betina gravid (sekitar 3-4 hari setelah nyamuk diberi pakan darah) dan diberi makan larutan sukrosa $10 \%$ yang diresapkan pada sepotong kapas. Pengamatan dilakukan setiap hari sampai dengan hari ke-7 setelah pengujian dilaksanakan. Pada hari ke-7, ovitrap dikeluarkan untuk dihitung jumlah telur pada tiap-tiap ovitrap menggunakan counter dan mikroskop dissecting. Bila terdapat telur pada air, akan disaring dan jumlahnya ditambahkan ke jumlah telur pada kertas saring. Selanjutnya telur dikembalikan pada media untuk ditetaskan. Pakan larva yang sudah dicairkan ditambahkan secukupnya ke dalam masing-masing ovitrap. Mortalitas larva diamati dengan perbandingan larva pada ovitrap pembanding (ovitrap tanpa temefos) dan kontrol. Waktu pengamatan 
berakhir setelah tidak ditemukan larva yang hidup pada ovitrap perlakuan atau jika semua larva pada ovitrap kontrol telah menjadi nyamuk dewasa. Setelah pengamatan terhadap mortalitas larva selesai atau semua larva pada kontrol menjadi dewasa, kertas saring berisi telur diperiksa di bawah mikroskop. Dihitung jumlah telur yang cangkangnya terbuka sebagai indikasi telur yang menetas, dan dihitung juga telur yang masih utuh cangkangnya. Telur yang masih utuh cangkangnya pada pengamatan di bawah mikroskop akan ditekan dengan ujung jarum seksi agar pecah untuk melihat keberadaan embrionya.

\section{HASIL}

Dapat dilihat pada Tabel 1 jumlah telur Ae. aegypti yang ditemukan pada ovitrap dengan berbagai jenis atraktan. Jumlah telur paling banyak ditemukan pada
ARJ yaitu sebesar $36,1 \%$ untuk air rendaman jerami saja dan $31,4 \%$ untuk air rendaman jerami padi + temefos. Telur paling sedikit ditemukan pada ovitrap dengan aquades yaitu sebesar $6,1 \%$ untuk aquades saja dan 6,8\% ovitrap dengan aquades + Temefos. Tidak ada telur yang menetas dari ovitrap dengan campuran temefos, baik itu ARJ, ABT, maupun aquades (Tabel 1).

Pengamatan terhadap perkembangan nyamuk Ae. aegypti pra-dewasa berdasarkan jenis air/ atraktan didapatkan hasil dengan berbedaan yang signifikan $(\mathrm{p}<0,05)$ dimana jenis atraktan dengan kandungan temefos tidak dapat menjadi media perkembangan nyamuk $(0 \%)$ sedangkan yang tertinggi adalah atraktan ARJ $(92,79 \%)$ dan terendah adalah ABT (29,57\%)( Tabel 2).

Tabel 1. Hasil Pengujian beberapa atraktan sebagai lethal ovitrap nyamuk Ae. aegypti

\begin{tabular}{|c|c|c|c|c|c|c|c|c|}
\hline \multirow[b]{2}{*}{ Atraktan } & \multicolumn{4}{|c|}{ Pengulangan ke- } & \multirow[b]{2}{*}{ Jumlah } & \multirow{2}{*}{$\begin{array}{c}\% \\
\text { Jumlah } \\
\text { Telur }\end{array}$} & \multirow{2}{*}{$\begin{array}{c}\text { Jumlah } \\
\text { larva } \\
\text { hidup }\end{array}$} & \multirow{2}{*}{$\begin{array}{c}\% \\
\text { Menetas }\end{array}$} \\
\hline & 1 & 2 & 3 & 4 & & & & \\
\hline$\overline{\text { ARJP }}$ & 298 & 209 & 293 & 254 & 1054 & 36,1 & 978 & 92,79 \\
\hline ARJP + Temefos & 261 & 234 & 171 & 252 & 918 & 31,4 & 0 & 0,00 \\
\hline $\mathrm{ABT}$ & 70 & 109 & 71 & 78 & 328 & 11,2 & 97 & 29,57 \\
\hline $\mathrm{ABT}+$ Temefos & 5 & 50 & 112 & 79 & 246 & 8,4 & 0 & 0,00 \\
\hline Aquadest & 22 & 0 & 109 & 47 & 178 & 6,1 & 151 & 84,36 \\
\hline $\begin{array}{l}\text { Aquades + } \\
\text { Temefos }\end{array}$ & 38 & 37 & 7 & 115 & 179 & 6,8 & 0 & 0,00 \\
\hline
\end{tabular}


Tabel 2. Hasil Analisis LSD terhadap Perbedaan Jumlah Telur yang Menetas pada Masing-masing Jenis Atraktan

\begin{tabular}{|c|c|c|c|}
\hline \multirow{2}{*}{ Variabel } & \multicolumn{2}{|c|}{ Jenis Atraktan } & \multirow{2}{*}{$\begin{array}{l}\text { Signi- } \\
\text { fikansi }\end{array}$} \\
\hline & 1 & 2 & \\
\hline \multirow{30}{*}{$\begin{array}{l}\text { Jumlah } \\
\text { Telur }\end{array}$} & \multirow{5}{*}{ ARJP } & $\begin{array}{l}\text { ARJP + } \\
\text { temefos }\end{array}$ & .256 \\
\hline & & $\mathrm{ABT}$ & $.000 *$ \\
\hline & & $\begin{array}{l}\text { ABT + } \\
\text { Temefos }\end{array}$ & $.000^{*}$ \\
\hline & & Aquadest & $.000^{*}$ \\
\hline & & $\begin{array}{l}\text { Aquadest + } \\
\text { temefos }\end{array}$ & $.000 *$ \\
\hline & \multirow{5}{*}{$\begin{array}{l}\text { ARJP + } \\
\text { temefos }\end{array}$} & ARJP & .256 \\
\hline & & $\mathrm{ABT}$ & $.000^{*}$ \\
\hline & & $\begin{array}{l}\text { ABT + } \\
\text { Temefos }\end{array}$ & $.000 *$ \\
\hline & & Aquadest & $.000^{*}$ \\
\hline & & $\begin{array}{l}\text { Aquadest + } \\
\text { temefos }\end{array}$ & $.000 *$ \\
\hline & \multirow{5}{*}{ ABT } & ARJ & $.000 *$ \\
\hline & & $\begin{array}{l}\text { ARJ + } \\
\text { temefos }\end{array}$ & $.000^{*}$ \\
\hline & & $\begin{array}{l}\mathrm{ABT}+ \\
\text { Temefos }\end{array}$ & .489 \\
\hline & & Aquadest & .212 \\
\hline & & $\begin{array}{l}\text { Aquadest + } \\
\text { temefos }\end{array}$ & .274 \\
\hline & \multirow{5}{*}{$\begin{array}{l}\text { ABT + } \\
\text { Temefos }\end{array}$} & ARJ & $.000^{*}$ \\
\hline & & $\begin{array}{l}\text { ARJ + } \\
\text { temefos }\end{array}$ & $.000^{*}$ \\
\hline & & $\mathrm{ABT}$ & .489 \\
\hline & & Aquadest & .565 \\
\hline & & $\begin{array}{l}\text { Aquadest + } \\
\text { temefos }\end{array}$ & .678 \\
\hline & \multirow{5}{*}{ Aquadest } & ARJ & $.000 *$ \\
\hline & & $\begin{array}{l}\text { ARJ + } \\
\text { temefos }\end{array}$ & $.000 *$ \\
\hline & & $\mathrm{ABT}$ & .212 \\
\hline & & $\begin{array}{l}\text { ABT + } \\
\text { Temefos }\end{array}$ & .565 \\
\hline & & $\begin{array}{l}\text { Aquadest + } \\
\text { temefos }\end{array}$ & .872 \\
\hline & \multirow{5}{*}{$\begin{array}{l}\text { Aquadest + } \\
\text { temefos }\end{array}$} & ARJ & $.000^{*}$ \\
\hline & & $\begin{array}{l}\text { ARJ + } \\
\text { temefos }\end{array}$ & $.000^{*}$ \\
\hline & & $\mathrm{ABT}$ & .274 \\
\hline & & $\begin{array}{l}\mathrm{ABT}+ \\
\text { Temefos }\end{array}$ & .678 \\
\hline & & Aquadest & .872 \\
\hline
\end{tabular}

*berbeda signifikan

\section{PEMBAHASAN}

Hasil perhitungan jumlah telur menunjukan bahwa atraktan ARJP menghasilkan telur terbanyak. Hal ini juga diperkuat oleh hasil analisis LSD yang menunjukkan adanya perbedaan signifikan jumlah telur dengan atraktan lainnya. Atraktan ARJP+temefos menghasilkan jumlah telur tertinggi kedua. Hal ini menunjukkan ada indikasi kecenderungan nyamuk lebih tertarik bertelur pada media yang mengandung jenis atraktan tersebut dibandingkan pada media yang lain. Media dengan atraktan mengandung senyawa organik dan anorganik berpengaruh terhadap aroma yang dapat menjadi daya tarik bagi nyamuk Ae. aegypti betina dalam memilih media untuk meletakkan telurnya sehingga dapat dikatakan bahwa atraktan ARJP positif berpengaruh terhadap perilaku bertelur. Konsentrasi atraktan ARJP 15\% dalam penelitian ini cukup optimum dibandingkan dengan penelitian terdahulu dengan konsentrasi 20\%. Dengan konsentrasi tersebut mampu menetaskan hampir 93\% telur yang dihasilkan. Atraktan kedua yang menetaskan telur sebanyak 84\% adalah ABT, sedangkan atraktan dengan campuran temefos $(0,02 \%)$ meskipun menghasilkan banyak telur namun tidak mampu menetaskannya menjadi larva. Hal ini mengambarkan bahwa temefos masih memiliki kualitas cukup baik sebagai larvasida nyamuk Ae. aegypti meskipun sejak tahun 1998 pernah dilaporkan bahwa status kerentanan terhadap temefos telah menurun sebesar $50 \%$ dari populasi larva nyamuk $A e$. aegypti di Kota Banjarbaru (Ridha, M. Rasyid., Wulan sembiring, 2018).

Pengamatan terhadap perkembangan nyamuk Ae. aegypti pra dewasa berdasarkan jenis air/ atraktan didapatkan perbedaan yang signifikan antara media yang ditambahkan temefos dengan media tanpa temefos. Pemilihan tempat untuk bertelur dipengaruhi oleh berbagai faktor, seperti indra penglihatan, penciuman, suhu, cahaya, kelembaban, dan fisik media tempat peletakan telur. Peletakan telur juga dipengaruhi oleh pertumbuhan ovarium yang sempurna (Yahya dan Esi, 2017). Secara teoritis nyamuk Ae. aegypti hanya mau berkembang biak pada tempat yang berisikan air jernih misalnya di dalam kaleng bekas, pecahan botol, pot bunga, tempat minum burung, gentong, bak mandi dan lain sebagainya (Yahya., Esi, 2017), (Ikawati, Ayu and Meilani, 2015). Namun hasil pengujian menunjukan perubahan perilaku dalam meletakkan telur. Hal ini sudah pula ditemukan pada beberapa penelitian yang menunjukan perilaku meletakkan telur 
nyamuk Ae. aegypti pada air yang kurang bersih/jernih (Yahya, 2017). Hasil penelitian lainnya juga mendapatkan larva Ae. aegypti mampu bertahan pada air selokan hingga menjadi pupa (Baharuddin, 2015), dan pada pH (derajat keasaman) 4-10 serta salinitas yang berbeda (Air and Cahyati, 2017), (Arduino et al., 2015). Penelitian lain juga menunjukan bahwa bahwa larva Ae. aegypti dapat bertahan hidup pada rendaman air enceng gondok dan air lindi karena mengandung zat ammonia yang cukup tinggi (Indira and Tarwotjo, 2017). Pemilihan tempat untuk meletakkan telur sendiri dipengaruhi oleh kandungan zat organik dan amonia. Menurut Wong et al. (2011), tingginya bahan organik menjadikan media memiliki ketersediaan pakan yang cukup untuk kelangsungan hidup dan pertumbuhan keturunan selanjutnya. Senyawa amonia sendiri terbentuk dari proses fermentasi zat organik. Bahan organik akan menghasilkan senyawa ammonia dan karbondioksida yang mempengaruhi saraf penciuman Ae. aegypti dimana rangsangan kimia yang berupa senyawa ammonia menjadi atraktan untuk mendorong nyamuk betina meletakkan telurnya (Wong et al., 2011). Hal ini mengindikasikan adanya pergeseran perilaku Ae. aegypti dalam memilih tempat perindukan dan membuktikan adanya pergeseran perilaku nyamuk Ae. aegypti dalam beradaptasi dengan lingkungan, artinya bila tidak menemukan perindukan air bersih maka nyamuk bisa beralih ke air kurang bersih atau atraktan (air rendaman zat organik), air kotor seperti selokan, dan bahkan air sumur gali dengan dasar tanah (Gonzalez et.al., 2016). Menurut Yotopranoto dalam Agustin (2017) faktor penting yang mempengaruhi persentase menetasnya telur nyamuk Ae. aegypti dan perkembangannya adalah suhu, dan $\mathrm{pH}$ serta apabila faktor-faktor tersebut pada keadaan optimal maka akan mendukung tingginya perkembangan nyamuk pada suatu media, sebaliknya apabila keadaan kurang optimal akan menghambat atau bahkan menghentikan pertumbuhan dan perkembangan nyamuk $A e$. aegypti pra-dewasa (Indira and Tarwotjo, 2017).

Keseluruhan hasil menggambarkan bahwa nyamuk Ae. aegypti mampu berkembang biak dan menjadi dewasa di luar air bersih. Kemungkinan pada masa yang akan datang, peningkatan penyakit DBD akan semakin tinggi. Oleh karena itu hasil penelitian ini diharapkan menjadi acuan bagi instansi terkait agar memperluas pengendalian nyamuk Ae. aegypti ke tempattempat yang selama ini tidak biasa dilakukan pengendalian. Apabila dari instansi pemerintah, swasta, dan masyarakat tidak mewaspadai kemampuan adaptasi dari nyamuk $A e$. aegypti maka penyakit DBD akan semakin cepat menyebar di seluruh wilayah bahkan bisa menimbulkan Kejadian Luar Biasa.

Dari hasil analisis data terdapat pengaruh jenis atraktan terhadap daya tetas dan perkembangan Ae. aegypti menjadi nyamuk dewasa. Penelitian membuktikan bahwa Ae. aegypti dapat berkembang biak menjadi dewasa di luar media air bersih. Uji dilanjutkan dengan uji post hoc menggunakan LSD dengan nilai signifikansi beragam antar jenis atraktan. Dari semua jenis atraktan hanya terdapat 4 pasang jenis atraktan dengan hasil uji LSD tidak didapatkan perbedaan yang bermakna yaitu 1) ARJP dan ARJP + temefos; 2) ABT dan $\mathrm{ABT}+$ temefos; 3) $\mathrm{ABT}$ dan aquadest; 4) ABT dan aquadest + temefos; 5) $\mathrm{ABT}+$ temefos dan aquades; 6) ABT + temefos dan aquades + temefos; 7 ) aquades dan aquades + temefos $(\mathrm{p}>0,05)$.

\section{KESIMPULAN DAN SARAN}

\section{Kesimpulan}

Berdasarkan hasil penelitian dapat disimpulkan bahwa kombinasi lethal ovitrap yang paling efektif adalah campuran atraktan air rendaman jerami padi + temefos, sehingga dapat direkomendasikan untuk diuji coba sebagai metode alternatif dalam pengendalian kepadatan vektor DBD (nyamuk Ae. aegypti) di suatu wilayah.

\section{Saran}

Perlu dilakukan ujicoba lapangan untuk mengetahui efektifitas campuran rendaman jerami dan temefos. 


\section{UCAPAN TERIMAKASIH}

Terimakasih diucapakan kepada Kepala Balai Litbang Kesehatan Tanah Bumbu yang memberikan kesempatan dalam pengujian ini, dan teman-teman Laboratorium Entomologi yang telah membantu pengujian di Laboratorium.

\section{DAFTAR PUSTAKA}

Air, D. A. N. S., Anggraini, T. S. and Cahyati, W. H. (2017) 'Perkembangan Aedes aegypti Pada Berbagai pH Air Dan Salinitas Air', Higeia Journal Of Public Health, 1(3), pp. 1-10.

Arduino, M. D. B. et al. (2015) 'Effect of salinity on the behavior of Aedes aegypti populations from the coast and plateau of southeastern Brazil', Journal of vector borne diseases, 52(1), pp. 79-87.

Ariani, P. L. and Widana, I. N. S. (2016) 'Pengaruh Air Rendaman Jerami Pada Ovitrap Terhadap Jumlah Telur Nyamuk Demam Berdarah (Aedes sp) Yang Terperangkap', Emasains, 5(1), pp. 8-12.

Baharuddin, A. (2015) 'Karakteristik Breeding Places Dan Pertumbuhan Larva Aedes aegypti', Jurnal Kesehatan Tadulako, 1(2), pp. 61-71.

Codeço, C. T. et al. (2015) 'Surveillance of Aedes aegypti : Comparison of House Index with Four Alternative Traps', PLoS Negl Trop Dis, 9(2), pp. 1-23. doi: 10.1371/journal.pntd.0003475.

Gonzalez, Paula V., Paola A. González Audino, and H. M. M. (2016) 'Oviposition behavior in Aedes aegypti and Aedes albopictus (Diptera: Culicidae) in response to the presence of heterospecific and conspecific larvae.', Journal of medical entomology, 53(2), pp. 268-272.

Ikawati, B., Ayu, R. and Meilani, R. (2015) 'Pengaruh Konsentrasi Kaporit Terhadap Daya Tetas Telur Aedes aegypti', Spirakel, 7(2), pp. 1-7.

Indira Agustin , Udi Tarwotjo, R. R. (2017) 'Perilaku Bertelur Dan Siklus Hidup Aedes aegypti', J Biologi, 6(4), pp. 5-10.

Kemenkes (2017) 'Kemenkes optimalkan psn cegah dbd', Kementerian Kesehatan Republik Indonesia, pp. 1-2.

Widya, I Gusti Agung Ngurah P, Sudjari, Habiba Aurora'. (2015) 'Uji Perbandingan Potensi Penambahan Ragi Tape dan Ragi Roti pada Larutan Gula sebagai Atraktan Nyamuk Aedes sp ., Majalah Kesehatan FKUB, 2(4), pp. 181-185.

Milana Salim and Tri Baskoro Tunggul Satoto (2015) 'Uji Efektifitas Atraktan pada Lethal Ovitrap terhadap Jumlah dan Daya Tetas Telur Nyamuk Aedes aegypti', Buletin Penelitian Kesehatan, 43(3), pp. 147-154.
Nurin-Zulkifli, I. M., Chen, C. D., IM Nurin-Zulkifli, CD Chen, O Wan-Norafikah, HL Lee, K Faezah, A. I. and AG Abdullah, KW Lau, Y Norma-Rashid, M. (2015) 'Temporal Changes Of Aedes And Armigeres Populations In Suburban And Forested Areas', SoutheaSt aSian J trop Med public health, 46(4), pp. 574-585.

Poole-smith, B. K. et al. (2015) 'Comparison of Vector Competence of Aedes mediovittatus and Aedes aegypti for Dengue Virus: Implications for Dengue Control in the Caribbean', PLoS Negl Trop Dis, 9(2), pp. 111. doi: 10.1371/journal.pntd.0003462.

Rati, G., Hasmiwati and Rustam, E. (2016) 'Perbandingan Efektivitas Berbagai Media Ovitrap terhadap Jumlah Telur Aedes Spp yang Terperangkap di Kelurahan Jati Kota Padang', Jurnal Kesehatan Andalas, 5(2), pp. 385-390.

Ridha, M. Rasyid., Wulan sembiring, . Abdullah Fadilly. (2018) 'Ridha, M. Rasyid. Indikator Entomologi Dan Status Resistensi Vektor Demam Berdarah Dengue (Aedes aegypti $\mathrm{L}$ ) Terhadap Beberapa Golongan Insektisida Di Kota Banjarbaru. (2018).', in Prosiding Seminar Nasional Seri 8: mewujudkan masyarakat madani dan lestari. LPPM UII Yogyakarta, pp. 86-96.

Sari;, A. K., Octaviana, D. and Wijayanti, S. P. M. (2017) 'Perbedaan efektifitas penggunaan atraktan larutan fermentasi gula-ragi dan air rendaman cabai merah (Capsicum annum) terhadap jumlah telur Aedes sp. yang terperangkap', Jurnal Kesmas Indonesia, $9(2)$, pp. 60-68.

Wahidah, A., Martini and Hestiningsih, R. (2016) 'Efektivitas jenis atraktan yang digunakan dalam ovitrap sebagai alternatif pengendalian vektor DBD di Kelurahan Bulusan', Jurnal Kesehatan Masyarakat, 4(1), pp. 106-115.

Wong, J. et al. (2011) 'Oviposition site selection by the dengue vector Aedes aegypti and its implications for dengue control', PLOS Neglected Tropical Diseases, 5(4). doi: 10.1371/journal.pntd.0001015.

Yahya., Esi, S. (2017) 'Daya Tetas dan Perkembangan Larva Aedes aegypti Menjadi Nyamuk Dewasa pada Tiga Jenis Air Sumur Gali dan Air Selokan', Jurnal Vektor Penyakit, 11(1), pp. $9-18$

Yahya, S. E. W. (2017) 'Daya Tetas dan Perkembangan Larva Aedes aegypti Menjadi Nyamuk Dewasa pada Tiga Jenis Air Sumur Gali dan Air Selokan', Jurnal Vektor Penyakit, 11(1), pp. 9-18.

Young, K. I. et al. (2017) 'Abundance and distribution of sylvatic dengue virus vectors in three different land cover types in Sarawak, Malaysian Borneo'. Parasites \& Vectors, pp. 1-14. doi: 10.1186/s13071-017-2341-z. 